\title{
THE EAST ANTARCTIC ICE SHEET: THE PROBLEM OF PALAEOGLACIOLOGICAL RECONSTRUCTION
}

\author{
(Abstract only)
}

\author{
by \\ V. I. Bardin \\ (c/o Dr V. M. Kotlyakov, Institute of Geography, Academy of Sciences of the U.S.S.R., \\ Staromonetny per. 29, Moscow 109017, U.S.S.R.)
}

ABSTRACT

Palaeoglaciological studies, including glaciogeomorphological observations and comprehensive studies of the composition of glacial deposits, undertaken by scientists of a number of countries, enable the major stages in the evolution of glaciation of some regions of East Antarctica to be outlined.

In this report, palaeoglaciological reconstructions for certain key territories: Queen Maud Land, Mac. Robertson Land, and Victoria Land are considered. The completeness and reliability of such reconstructions are also discussed.

The region of Prince Charles Mountains

(Mac. Robertson Land) turned out to be one of the most significant for palaeoglaciology. In this region, the author has discovered and studied glacial deposits of at least six age stages, their formation having taken place during approximately $20 \mathrm{Ma}$.

An attempt is made to compare the results of regional studies and to present the evolution of the development of the whole East Antarctic ice sheet in space and time.

Different examples of palaeoglaciological reconstructions of the ice sheet of East Antarctica are presented, the possibilities of different approaches are evaluated practically, and schematic maps of the change in glaciation of East Antarctic regions at different evolutional stages, compiled by the author, are presented for discussion.

\section{THE VERTICAL STRUCTURE OF THE}

\section{ANTARCTIC ICE SHEET AND PALAEOCLIMATIC INTERPRETATION OF THE DATA}

\author{
(Abstract only) \\ by \\ Ye. Korotkevich, V. N. Petrov, N. I. Barkov and V. Ya. Lipenkov \\ (Arctic and Antarctic Research Institute, Leningrad, U.S.S.R.) \\ sheet (down to $300 \mathrm{~m}$ depth) formed during the past \\ $12 \mathrm{ka}$, and grew under temperatures higher than those \\ at which the lower part of the ice formed, that is \\ ice at 300 to $700 \mathrm{~m}$ depth. This conclusion was con- \\ firmed by the results of oxygen isotope analysis. \\ The air content of ice at depths 100 to 650 , \\ 650 to 850,850 to 1100 , and 1100 to $1400 \mathrm{~m}$ reduced \\ to normal conditions was $65,70,75$, and $70 \mathrm{~mm}^{3} \mathrm{~g}^{-1}$ \\ respectively. Calculations suggest that 3 to $30 \mathrm{ka} B P$ \\ the ice-sheet elevation at Vostok station was close \\ to the present one, while 30 to 40,40 to 55, and 55 \\ to $75 \mathrm{ka} \mathrm{BP}$ it was 500,1000 , and $500 \mathrm{~m}$ lower than \\ at present, respectively.
}

\begin{abstract}
The ice core from the $1415 \mathrm{~m}$ Vostok bore hole has been studied. It was found that the ice-grain size increases with depth in the upper $700 \mathrm{~m}$, a sharp gradient change occurring in the 300 to $400 \mathrm{~m}$ range. The grain cross-section area at depths of 100,200 , $300,400,500,600$, and $700 \mathrm{~m}$ was $1.1,2.0,1.5,1.9$, 2.6 , and $3.3 \mathrm{~mm}^{2}$ respectively. Since grain size is a function of age, and is determined by initial size and growth rate, the latter being exponentialiy related to ice temperature, an attempt was made to interpret the obtained data in terms of palaeoclimatology. Calculations show that the upper part of the ice
\end{abstract}

